\title{
GOVERNMENT PARTNERS OF THE BOLSHEVIKS
}

\author{
THE RUSSIAN SOCIALIST REVOLUTIONARIES IN THE \\ FAR EASTERN REPUBLIC, 1920-22
}

Little is known about the role played by the Socialist Revolutionaries and the Mensheviks in the so-called Far Eastern Republic, an independent state, at least in name, in Eastern Siberia during the early 'twenties. Based mainly on material in the archive of the Party of Socialist Revolutionaries, this note wants to shed some light on the events in the area at the time. Unfortunately the author did not have access to a sufficient amount of material from Menshevik archives to detail the Menshevik contribution to the Far Eastern Republic, but we shall see how the Bolsheviks adopted from the Socialist Revolutionaries and the Mensheviks the idea to form this kind of state, and how they subsequently gained a hold upon the Far Eastern Republic.

The Socialist Revolutionaries formed one of the revolutionary parties that opposed Russian Tsarism. After the February Revolution of 1917 they took part in the Provisional Government. However, after the Bolsheviks took over control in the October Revolution of the same year, and in spite of their victory at the polls in the elections for the Constituent Assembly, the Socialist Revolutionaries were pushed into the role of the opposition, and they were even persecuted by the Bolsheviks. In this they shared their lot with the Mensheviks. A contentious issue between the Socialist Revolutionaries and the Bolsheviks, and a very important one at that, concerned the matter of the form of government. The Socialist Revolutionaries were in favour of a parliamentary democracy, the Bolsheviks wanted a Soviet system which, in fact, meant the dictatorship of their party.

Whereas in Central Russia the Bolsheviks persecuted the Socialist Revolutionaries and the Mensheviks, in the Russian Far East (as Eastern Siberia was known) the latter two were the very partners the Bolsheviks needed. Early in 1920 the power of the "Whites", the counter-revolutionary opposition to the Bolsheviks, had collapsed in the region. Obviously, the Soviet Government wanted to extend its control to this region, which had 
been part of Russia for centuries, but this could not easily be done. The point is that around 1920 Eastern Siberia was still the battle ground of international politics. Since 1918 Japan, at the time the biggest power in the Far East, had an intervention force in Eastern Siberia. The United States, anxious that Japan should not engage in too large an expansion of power, kept an eye on the development of events. With respect to its political aims in the Far East, Russia, now represented by the Soviet Government, had to reckon with the interests of the other two great powers.

At that moment, annexation of Eastern Siberia by Soviet Russia probably would have led to an armed conflict with Japan, and to the further risk of a Japanese occupation of the whole region, as well as intervention by the United States. The Soviet Government wanted to prevent this. A solution of the problem was found in the notion of a "buffer state". In the disputed region an independent state should be formed which for the time being would act as a buffer between Russia and Japan. This solution was not, initially, proposed by the Soviet Government, but by its political adversaries, the Socialist Revolutionaries and the Mensheviks. They saw an opportunity to put into practice their democratic ideals.

The Soviet Government reacted positively, but wanted the newly formed buffer state to be independent in name only. In fact it should be a kind of satellite state controlled by Moscow, although it could have a democratic appearance. In order to oblige the foreign powers other political parties, i.e. the Socialist Revolutionaries and the Mensheviks, were allowed to participate in the government, provided they had no real power. The fact that at the same time these parties were persecuted in Soviet Russia did not keep the Bolsheviks from entering into negotiations with them on these issues in the Far East.

The negotiations started in January 1920. In the same month the power of Admiral Kolchak, the "White" leader in Siberia, came to a definitive end. Whilst the Red Army had not advanced beyond Tomsk, a "Political Centre" formed by the Socialist Revolutionaries and the Mensheviks took power in Irkutsk. The Political Centre sent a delegation to Tomsk, and on January 19th they reached an agreement with the Bolsheviks to establish a buffer state east of the river Oka, a subsidiary of the Angara, and east of the river Angara itself, an area which would also include Irkutsk and Lake Baikal. ${ }^{1}$ On January 21 st a telegram from Moscow brought the ratification of the agreement by Lenin and Trotskii. ${ }^{2}$

1 Zhurnal ob"edinennogo zasedaniia Mirnoi Delegatsii Politicheskogo Tsentra s Revvoensovetom Piatoi Armii i Sibrevkomom, January 19, 1920, PSR Archive, No 2063, Internationaal Instituut voor Sociale Geschiedenis.

2 V. I. Lenin, Polnoe sobranie sochinenii, 5th ed. (Moscow, 1958-70), LI, p. 334. 
The same day, however, the agreement became dubious, as local Bolsheviks in Irkutsk took over control from the Political Centre. Thereafter the Bolsheviks were no longer prepared to agree to the formation of a buffer state including Irkutsk, the only administrative and economic centre of significance in the whole region. A large section of Lake Baikal as well had to be excluded from the new state. In addition, to the Bolsheviks the new state could only be nominally independent and democratic. Admittedly, its government would be formed by a coalition of Socialist Revolutionaries, Mensheviks and Bolsheviks, ${ }^{3}$ but the actual control over the armed forces of the new state would be in the hands of the Red Army. ${ }^{4}$

These conditions were unacceptable to the Socialist Revolutionaries and the Mensheviks, who did not want to create a quasi-democratic satellite state for Moscow. Their political objective was a state, really and truly independent and democratic, that should also include Irkutsk. Consequently they refused to co-operate in the forming of a buffer state that would meet the demands of the Bolsheviks. This was a set-back for the Soviet aims in Eastern Siberia, and Lenin was prepared if need be to force the Socialist Revolutionaries and the Mensheviks to participate in the proposed form of government. On March 9th Lenin dispatched a telegram reading: "The Mensheviks and SRs must unconditionally join the government of the buffer state. If they do not unconditionally submit to our demands, they will be arrested." 5

However, now the Socialist Revolutionaries and the Mensheviks were only prepared to take part in local bodies that were democratically instituted. Early in March 1920 they formed, together with the Bolsheviks, a government for the Baikal Province in Verkhneudinsk, today Ulan-Ude. This government was led by a Menshevik. It turned out, however, that the Bolsheviks who ran the show wanted this to be the beginning of a buffer state after their own ideas, and soon the Socialist Revolutionaries and the Mensheviks withdrew from the government. Without their partners the Bolsheviks then proclaimed themselves to be the government of the "Far Eastern Republic". In May the Republic was formally acknowledged by the Soviet Government. For the time being it merely consisted of the Baikal Province, and it was entirely controlled by the Bolsheviks and their adherents.

Elsewhere in the Russian Far East, viz., in Vladivostok and the Maritime

3 Protokol zasedaniia Mirnoi Delegatsii Politicheskogo Tsentra i predstavitelei Sibrevkoma i Revvoensoveta Piatoi Armii, Krasnoiarsk, January 24, PSR Archive, No 2063.

4 Protokol ob"edinennogo zasedaniia Kraevykh Komitetov PSR i RSDRP s predstaviteliami RKP, February 24 , ibid.

5 Lenin, Polnoe sobranie sochinenii, LI, pp. 156, 413. 
Province, the original democratic idea of a buffer state stood a better chance. As here the Japanese forces were concentrated, the Bolsheviks were rather prepared to make some concessions. Although in the area they were pulling the political strings, after the collapse of Admiral Kolchak's power they did not altogether take over the Vladivostok region. They established a coalition government under the leadership of the Socialist Revolutionary A. S. Medvedev. All the same, the Bolsheviks saw to it that they had control over the army and the economy. Thus a situation arose in which the Bolsheviks could operate behind the façade of a government with a Socialist Revolutionary leader.

The Japanese, however, were not deceived. Early in April they took the offensive, and sent reinforcements to Vladivostok and the Maritime Province. They did not manage to set up a puppet government, but to the Bolsheviks it was quite clear that, if they wished to prevent a total Japanese occupation of the region, they had to restrain their political ambitions. And so they did. During the following months the Maritime Province developed into a reasonably democratic state, considering the circumstances. It had a coalition government which was responsible to an elected Popular Assembly. The Bolsheviks also participated in the government, but they were abiding by the rules of the democratic game. In August 1920 the Socialist Revolutionary F. S. Mansvetov reported: "At present the Maritime Province has a truly democratic government which rules by democratic means only."6

However, the establishment of a buffer state for the whole of the Russian Far East was not yet achieved. For the time being the region had a number of centres of power. The Far Eastern Republic, nominally democratic but in fact ruled by the Bolsheviks only, was limited to the Baikal Province. There was a democratic government in the Maritime Province and a Soviet administration of local Bolsheviks in the Amur Province. In addition, the "White" ataman Semenov ruled the Transbaikal Province, but in October he was ousted by the army of the Far Eastern Republic. Subsequently a conference was called in the capital of the Transbaikal Province, Chita, of representatives of the various regions in the Russian Far East. On November 10th they resolved to merge into the Far Eastern Republic. As the Socialist Revolutionaries and the Mensheviks still did not want to join the government, their conditions not being met, a government was formed consisting solely of Bolsheviks and their adherents.

Nevertheless, the Republic had to have the appearance of a democratic state, and in January 1921 elections were held for a Constituent Assembly.

6 Revoliutsionnaia Rossiia, No 2 (1921), p. 24. 
The Bolsheviks won 92 seats, and an alliance of peasants controlled by the Bolsheviks won 183 seats out of a total of 382 seats, together more than a two-thirds majority. Although this result may, in part, be due to some manipulation at the polls, it cannot be said that this was the only cause of the Bolshevik victory, because it seems that at the time the Bolsheviks in Eastern Siberia were rather popular. The largest party in opposition was formed by the Socialist Revolutionaries with 18 seats, supported by another alliance of peasants gaining 44 seats. $^{7}$

The Constituent Assembly adopted a constitution which in broad outline had a parliamentary character. The Bolsheviks looked upon the constitution as mere window-dressing, but the opposition parties wanted to put it into political practice. In this, they hoped to obtain the support of at least part of the Bolshevik-controlled peasant alliance. ${ }^{8}$ In order to give the Republic an outward appearance of democracy there was every reason to form a coalition government. In fact, talks between the various socialist parties started, but the Mensheviks and the Socialist Revolutionaries still were not prepared to co-operate merely for appearance's sake and thereby serve the goals of the Bolsheviks. As the latter did not want to give in to the demands of the opposition, the talks reached a deadlock.

In May 1921 the Japanese supported a right-wing coup in Vladivostok. The Socialist Revolutionaries now were afraid that reactionary forces again would advance in the whole region and in their opinion such a threat had to be met by joined forces. ${ }^{9}$ Talks re-opened and in July a coalition government was formed. Six out of thirteen Ministries were occupied by the opposition, three by the Mensheviks, two by the Socialist Revolutionaries and one by a Popular Socialist who did not join on behalf of his party. ${ }^{10}$

In spite of all earlier statements the Socialist Revolutionaries were now prepared to take part in a government controlled by the Bolsheviks, for the opposition had no real power. It had no representation on the collective presidential body. It held no key positions in the cabinet, and its representatives in the cabinet were treated as "unwanted visitors". 1 Moreover, the delegated cabinet ministers turned out not to be the most suitable men to represent their parties, because soon the three Mensheviks

${ }^{7}$ L. M. Papin, Krakh kolchakovshchiny i obrazovanie Dal'nevostochnoi Respubliki (Moscow, 1957), p. 201.

8 A. I. Pogrebetskii to V. Ia. Gurevich, Harbin, August 1, 1921, PSR Archive, No 2059.

9 Vypiska iz protokola zasedaniia Dal'biuro PSR, May 31, PSR Archive, No 2056.

10 See note 8 .

11 "Moisei" to the Maritime Province Committee of the PSR, Chita, July 15, PSR Archive, No 2062. 
and one of the two Socialist Revolutionaries turned their backs on their parties and reconciled themselves with the Bolsheviks. As early as December 1921 the coalition was dissolved by the Bolsheviks. ${ }^{12}$

In July 1922 new elections were held, this time for a Popular Assembly. The Bolsheviks and their political partners in the Peasant Alliance now won 85 out of 124 seats, the Socialist Revolutionaries won 18 seats, and the peasant faction supporting them won 12 seats. ${ }^{13}$ These are the figures found in the Soviet literature on the subject. According to the Socialist Revolutionary A. I. Pogrebetskii, however, his party won 20 seats and the opposition occupied more than one third of the total number of seats, with the result that the Bolsheviks did not have the two-thirds majority they needed to amend the constitution. ${ }^{14}$

Such a move could well be on the cards, as the Soviet Government now aimed at a change in the political status of Eastern Siberia. Without deeply going into the international political situation at the time it can be said that the foreign powers were no longer strongly opposed to the establishment of Soviet rule in the region. Apparently also under pressure of the United States Japan withdrew its forces from the Maritime Province in October 1922, and they remained only on the Island of Sakhalin.

If Pogrebetskii's figures about the distribution of seats in the Popular Assembly are correct, the only obstacle for the Soviets to achieve the annexation of the Far Eastern Republic was lying in the presence of the opposition in the Popular Assembly. Consequently, with the exception of Pogrebetskii, who at the time was staying abroad, in Harbin, all parliamentary delegates of the Socialist Revolutionaries were arrested on October 21st-22nd, together with a number of other leading Socialist Revolutionaries.

They were accused of having entered into a conspiracy with the remaining reactionary forces in Eastern Siberia, but the Bolsheviks did not make the slightest attempt to substantiate the accusations. The constitution excluded the possibility of sending them into exile without trial, but the Bolshevik-controlled government swiftly revoked the relevant clauses and exiled the prisoners to Novonikolaevsk, today Novosibirsk, in Soviet territory. From here they were sent to various prisons, concentration camps and places of exile. ${ }^{15}$ After this coup had rendered the opposition

${ }_{12}$ Nash Golos (Chita), December 20 and 21, Nicolaevsky Collection, No 145/14, Hoover Institution.

13 P. M. Nikiforov, Zapiski prem'era DVR, 2nd ed. (Moscow, 1974), p. 186.

${ }^{14}$ A. I. Pogrebetskii to the Foreign Delegation of the PSR, Harbin, November 2, 1922, PSR Archive, No 2078.

${ }^{15}$ Ibid.; Revoliutsionnaia Rossiia, No 33-34 (1924), pp. 36-38. 
defenceless the Popular Assembly, on November 14th, voted in favour of the Republic's union with Soviet Russia. The next day an enactment provided for the incorporation of the Republic into Soviet Russia.

The end of the Far Eastern Republic did not come as a surprise. As early as February 1920 the Vladivostok Bolshevik I. G. Kushnarev had declared that "the day after the departure of the Japanese Soviet rule will be esiablished" ${ }^{16}$ As long as the international political situation required such a course, the Soviet Government under its leader Lenin was prepared to pursue its political objectives in Eastern Siberia with moderation, and to restrain those local Bolsheviks who wanted to force an immediate take over of Soviet rule in the region. However, the Soviets saw to it that the effectual political power never slipped out of their hands. The Far Eastern Republic never was more than a satellite state, formally independent, but with the kind of democracy that Moscow allowed to exist, and with an army controlled by Moscow. The very moment the Japanese had left the region, and when in addition it had become clear that no foreign power would bid a halt to the establishment of Soviet rule in Eastern Siberia, there was no further reason to maintain the Far Eastern Republic.

From the point of view of power politics this was a logical course of action. But their political stratagem towards the Far Eastern Republic once more shows the Bolshevik contempt of democratic and constitutional forms of government. To them, democracy was a mere tactical means used as long as it served their purpose, and to be discarded the very moment it no longer was of any use. By the same token members of other political parties and factions could only refuse to submit themselves to Bolshevik rule at the peril of being arrested.

In spite of their experiences elsewhere in Soviet Russia the representatives of these other political parties, the Socialist Revolutionaries and the Mensheviks, to a certain extent let themselves and their position in the Far Eastern Republic be used by the Bolsheviks. Indeed, they were prepared to co-operate with the Bolsheviks, who did not look upon them as equal partners, yet they even joined governments that were evidently under control of the Bolsheviks. The attitude of the Socialist Revolutionaries can partly be explained by their putting national interests before party interests. In their eyes Eastern Siberia was, after all, part of Russia and not of Japan, and the Japanese, consequently, posed a greater threat to the nation than the Bolsheviks did. The Russian "reaction", as they called

16 Protokol ob"edinennogo zasedaniia Kraevykh Komitetov PSR i RSDRP s predstaviteliami RKP, February 25, 1920, PSR Archive, No 2063. 
it, too, was more despicable than the Bolsheviks. In addition, they did not take a very strong position in the region, as their authority was due to the ever changing international situation rather than to a strong support of the people. In fact, a large section of the local population was partial to the Bolsheviks.

Some Socialist Revolutionaries and their Menshevik partners showed little stamina in the face of the Bolsheviks and the Soviet regime. This led to an acquiescence on the part of some members of the opposition. The Socialist Revolutionary party leader V. M. Chernov, pointing at the political activities of his fellow party members in the Far East in December 1922 , described them as a bad example. ${ }^{17}$ In practical politics, however, the Socialist Revolutionaries no longer could follow any example, because after 1922 in Russia there was no longer a political role for them.

17 Protokol soveshchaniia chlenov PSR, Berlin, December 10-15, 1922, p. 66, PSR
Archive, No 2133. 